\title{
Evaluation of $n-3$ polyunsaturated fatty acid content in various foods: health impact assessment
}

\author{
Dejana Trbovićl ${ }^{*}$, Mirjana Lukićl, Radivoj Petronijević ${ }^{1}$, Brankica Lakićevićl, Mladen Rašeta ${ }^{l}$, \\ Ivana Branković Lazićl, Nenad Parunović ${ }^{1}$
}

A b s tra $\mathrm{c} t$ : The objectives of this study were to verify the on-label claims of foods labelled as rich in $n$-3 polyunsaturated fatty acids (FA) and to assess their potential effects on human health in relation to European legislation. All the foods tested, i.e., chicken meat, anchovy fish oil, linseed oil, shellfish, capsule oil concentrate, egg, cold-smoked mackerel, frozen seafood, squid, hake, salmon and sardine, were evaluated for their contribution to the amount of n-3 polyunsaturated FA (n-3 PUFA) and the ratio of n-6/n-3 PUFA in relation to European dietary regulations. Lipids were extracted from the samples and then detected using capillary gas chromatography with flame ionization. An intake of $250 \mathrm{mg}$ eicosapentaenoic acid plus docosahexaenoic acid (EPA+DHA) per day, which is sufficient for primary prevention of chronic diseases in healthy volunteers, was found for $100 \mathrm{~g}$ of the edible part of shellfish, frozen seafood, squid, salmon, anchovy fish oil, capsule oil concentrate, cold-smoked mackerel and sardine. The European regulation defines

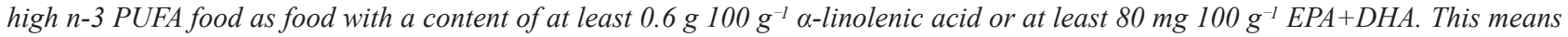

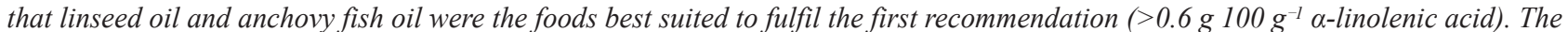
edible part of shellfish, frozen seafood, squid, hake, salmon, sardine, cold-smoked mackerel, capsule oil concentrate and anchovy fish

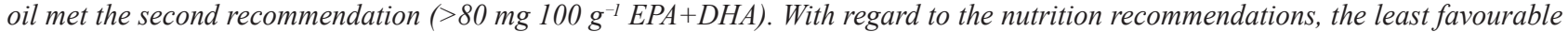
foods in terms of EPA+DHA content were eggs and chicken meat. An n-6/n-3 PUFA ratio closer to 4:1 is necessary for the prevention and treatment of chronic diseases. The results obtained in this study should be relevant for the establishment of Serbian tables of nutritional values of products.

Key words: total fat content, $n-3$ PUFA, $n-6$ PUFA, ratio n-6/n-3 PUFA.

\section{Introduction}

Fat in food consists mainly of fatty acids (FA), which are chemically coupled to glycerol. FA can be saturated (SFA), monounsaturated (MUFA) or polyunsaturated (PUFA) (Simopoulos, 2008; Gibson et al., 2013). Whereas PUFA have historically contained about one n-3 FA (omega in popular literature) for every four n-6 FA (1:4), modern diets can contain up to fifty to a hundred times more n-6 FA than n-3 FA (50:1) (Simopoulos et al., 2013). The evidence that this imbalance contributes to disease is now strong, and governments should formulate agricultural and food policies to influence costs (Simopoulos et al., 2013, Simopoulos, 2008). The n-6/n-3 PUFA ratio could again approach that to which we are genetically adapted, i.e. four to one (4:1) (Simopoulos, 2004; Simopoulos and Cleland, 2003). A high n-6/n-3 PUFA ratio is typical of Western and, increasingly, global diets and is associated with an increased risk of cardiovascular disease, obesity, type 2 diabetes and breast and prostate cancer, especially in people with genetic predispositions. Of concern, animal studies show that low intake of docosahexaenoic acid (DHA, C22:6n-3), an n-3 PUFA, combined with high intake of fructose leads to a metabolic syndrome in the brain (Agrawal and Gomez-Pinilla, 2012).

n-3 PUFA have numerous functions in the human body. They play an important role in the structure and function of biological membranes. Any increase in n-3 PUFA could cause changes in membrane fluids that can affect enzymatic activity, receptor-ligand interaction, cell interaction and nutrient transport through the membranes (Horrobin, 1995; von Schacky et al., 1985). Studies have shown that n-3 PUFA are essential for infant growth and development and for the prevention of various clinical conditions such as arthritis, diabetes, cancer and skin diseases.

Most diets, although with regional differences, are deficient in n-3 PUFA and too high in n-6 PUFA. A concerted effort is needed to narrow the $n-6 / n-3$

${ }^{1}$ Institute of Meat Hygiene and Technology, Kaćanskog 13, 11000 Belgrade, Republic of Serbia.

*Corresponding author: Dejana Trbović, dejana.trbovic@inmes.rs 
PUFA ratio in the diet. Consumers should be encouraged, through education and, if necessary, through government intervention to switch from oils with high n-6 PUFA content such as corn, safflower, and sunflower oil, to those with high n-3 PUFA content such as rapeseed and linseed oils and oils with high MUFA content such as olive oil or hazelnut oil in combination with rapeseed oil. The increased consumption of fish should also be emphasized. Scientists should work with the fishing industry to achieve this goal. Aquatic organisms and fish from aquaculture are the main source of the essential FA (Arts et al., 2001; Hunter and Roberts, 2000). The nutritional and health benefits of consuming fish and fish products are the reason for increased consumer demand for fish (Hunter and Roberts, 2000). Specifically, a 4:1 ratio of n-6/n-3 PUFA in the diet should be the goal (Simopulos, 2008, Simopoulos and Cleland, 2003). The aims of the present study were to verify the on-label claims of foods declared to be rich in n-3 PUFA and to assess their potential effects on human health.

\section{Materials and Methods}

\section{Food samples}

All foods tested were labelled as rich in $n-3$ PUFA: three chicken meat samples with skin, three anchovy fish oil samples, three linseed oil samples, eighteen edible shellfish samples, two capsule oil concentrate samples present on the Serbian market, six whole egg samples, three cold-smoked mackerel samples, three frozen seafood samples, three frozen squid samples, three frozen hake samples, three frozen salmon samples and eighteen edible part of sardine samples.

\section{FA analysis by capillary gas chromatography}

Total lipids for FA determination were extracted from products by accelerated solvent extraction (ASE 200, Dionex, Sunnyvale, CA) using a $33 \mathrm{ml}$ stainless steel cell according to the method of Spiric et al. (2010). Fatty acid methyl esters (FAMEs) in the extracted lipids were transesterificated using $0.25 \mathrm{M}$ trimethylsulfonium hydroxide (TMSH) in methanol (EN ISO 5509:2000). FAMEs were determined by gas-liquid chromatography (GLC, Shimadzu 2010, Japan) equipped with flame ionization detector and capillary HP-88 column (length $100 \mathrm{~m}$, i.d. $0.25 \mathrm{~mm}$, film thickness $0.20 \mu \mathrm{m})$. Injector and detector temperature were set at $250^{\circ} \mathrm{C}$ and $280^{\circ} \mathrm{C}$, respectively. Nitrogen was used as the carrier gas at flow rate of $1.33 \mathrm{~mL} \mathrm{~min}{ }^{-1}$. The injector split ratio was set at 1:50 and programmed column oven temperature started at $125^{\circ} \mathrm{C}$ and ended at $230^{\circ} \mathrm{C}$. Total analysis time was $50.5 \mathrm{~min}$. The chromatographic peaks in the samples were identified by comparing relative retention times of FAME peaks with peaks in Supelco 37 Component FAME mix standard (Supelco, Bellefonte, USA).

\section{Results and Discussion}

The average total fat, the total n-3 PUFA, $\alpha$-linolenic acid (ALA), eicosapentaenoic acid plus docosahexaenoic acid (EPA+DHA) and n-6/n-3 ratio of the 69 samples are presented in Table 1.

This study included twelve food types and provided total $\mathrm{n}-3$ PUFA in $\mathrm{g} 100 \mathrm{~g}^{-1}$ of samples, along with ALA, EPA and DHA contents. An intake of 250 mg per day of EPA+DHA is sufficient for primary prevention in healthy volunteers $(E F S A, 2010)$. This recommendation would be fulfilled when at least $100 \mathrm{~g}$ of shellfish, frozen seafood, squid, salmon, anchovy fish oil, capsule oil concentrate, cold-smoked mackerel or sardine are consumed (Table 1). The American Heart Association (AHA) recommends at least two portions of fish per week for general health; cardiovascular patients are advised to consume $1 \mathrm{~g}$ EPA+DHA per day and patients with hypertriglyceraemia, 2 to $4 \mathrm{~g}$ EPA+DHA per day ( $\mathrm{Li}-$ chtenstein et al., 2006). As shown in Table 1, foods, if consumed in $100 \mathrm{~g}$ amounts, that fulfil the minimal AHA recommendation for EPA+DHA intake (1 g per day) were anchovy fish oil, sardine, capsule oil concentrate and cold-smoked mackerel.

ALA cannot be synthesized by the body, but it is necessary to maintain "metabolic integrity" and is, therefore, considered an essential FA. However, there is not enough scientific data to derive an average requirement or a population reference intake (EFSA, 2010). The foods that were relatively high in ALA were linseed oil, anchovy fish oil, frozen salmon, chicken meat and cold-smoked mackerel. However, the Annex of Regulation EC No 1924/2006 defines a high n-3 PUFA food as a foodstuff con-

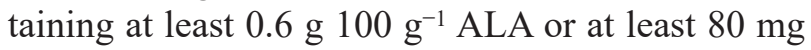
$100 \mathrm{~g}^{-1} \mathrm{EPA}+\mathrm{DHA}$. For fulfilling the first recommendation (0.6 g $100 \mathrm{~g}^{-1}$ ALA), linseed oil and anchovy fish oil were the most suitable foods. Shellfish, frozen seafood, squid, hake, salmon, sardine, cold-smoked mackerel, capsule oil concentrate and anchovy fish oil complied with the second recom-

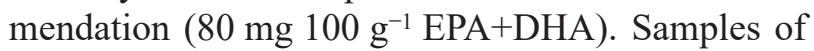
eggs and chicken meat were the most unfavourable 
Table 1. The content of total fat, n-3 PUFA, ALA, EPA+DHA and the n-6/n-3 FA ratio in foods

\begin{tabular}{|c|c|c|c|c|c|}
\hline Food sample & $\begin{array}{c}\text { Total fat } \\
\left(\mathrm{g} 100 \mathrm{~g}^{-1}\right)\end{array}$ & $\begin{array}{c}\text { n-3 FA } \\
\left(\mathrm{g} 100 \mathrm{~g}^{-1} \text { of }\right. \\
\text { sample) }\end{array}$ & $\begin{array}{c}\text { ALA } \\
\left(\mathrm{g} 100 \mathrm{~g}^{-1} \text { of }\right. \\
\text { sample) }\end{array}$ & $\begin{array}{c}\text { EPA+DHA, } \\
\left(\mathrm{g} 100 \mathrm{~g}^{-1} \text { of }\right. \\
\text { sample })\end{array}$ & $\begin{array}{c}\text { n- } 6 / n-3 \text { FA } \\
\text { ratio }\end{array}$ \\
\hline Eggs whole $(\mathrm{n}=6)$ & 9.85 & 0.07 & 0.04 & 0.03 & 12.01 \\
\hline Chicken meat with skin $(n=3)$ & 8.34 & 0.46 & 0.45 & 0.007 & 5.62 \\
\hline Anchovy fish oil $(\mathrm{n}=3)$ & 100 & 10.48 & 5.80 & 4.68 & 0.87 \\
\hline Linseed oil $(n=3)$ & 100 & 58.14 & 58.14 & 0 & 0.19 \\
\hline Shellfish $(\mathrm{n}=18)$ & 1.72 & 0.34 & 0.05 & 0.29 & 0.26 \\
\hline Capsule oil concentrate $(n=2)$ & 3.33 & 1.27 & 0.04 & 1.23 & 0.73 \\
\hline Mackerel cold-smoked $(\mathrm{n}=3)$ & 20.12 & 0.50 & 0.24 & 2.96 & 0.15 \\
\hline Seafood frozen $(n=3)$ & 3.92 & 0.84 & 0.15 & 0.69 & 0.48 \\
\hline Squid frozen $(n=3)$ & 2.48 & 0.48 & 0.03 & 0.45 & 0.11 \\
\hline Hake frozen $(\mathrm{n}=3)$ & 1.66 & 0.20 & 0.01 & 0.19 & 0.10 \\
\hline Salmon frozen $(n=3)$ & 11.69 & 1.10 & 0.54 & 0.56 & 0.53 \\
\hline Sardine $(\mathrm{n}=18)$ & 10.0 & 2.53 & 0.11 & 2.42 & 0.26 \\
\hline
\end{tabular}

Legend: $n$ - Number of samples examined

foods examined in terms of EPA+DHA content and n-6/n-3 ratio. The n-6/n-3 PUFA ratios in eggs were above the recommended levels of 4:1 (Simopoulos, 2002) and averaged 12.01 (egg samples examined), which was consistent with the previously published data for eggs from Hy-line hens housed in a cage system (Pavlovski et al., 2011). The n-6/n-3 PUFA ratios were higher in our study than in similar studies with Hy-line free range and Naked neck free range eggs (Pavlovski et al., 2011). The n-6/n-3 PUFA ratio of 5.62 in our chicken samples was lower than in the studies of Živković et al. (2017) and Milićević et al. (2014). With dietary manipulation, chicken meat enriched with n-3 PUFA with n-6/n-3 $<5$ can be produced (Penko et al., 2015).

The $n-6 / n-3$ PUFA ratio in frozen fish ranged from 0.10 (frozen hake) to 0.48 (frozen seafood), which were similar ratios to those of freshwater fish such as silver carp, Wells catfish and zander, namely from 0.33 to 0.93 (Ćirković et al., 2011). The $n-6 / n-3$ PUFA ratio of cold-smoked mackerel was 0.15 , similar to that of smoked salmon (Djordjević et al., 2016). Fish generally has high EPA+DHA ratios with low n-6/n-3 PUFA ratios, as was shown for rainbow trout with an n-6/n-3 PUFA ratio of $0.62-0.72$ (Trbović et al., 2012; Lušnic Polak et al., 2017) and carp reared with extruded or pelleted feed, with an n-6/n-3 PUFA ratio of 3.79 (Ćirković et al., 2011). Certainly, even more favourable $n-6 / n-3$ ratios in fish can be achieved by animal dietary measures.

\section{Conclusion}

Whereas the PUFA content of food declared as rich in n-3 PUFA have historically contained an n-6/n-3 PUFA ratio of about $1: 4$, modern diets can contain as much as 50:1. A concerted effort is needed to decrease the ratio of $n-6 / n-3$ PUFA in modern human diets. The aim of the present study was to verify food samples labelled as rich in n-3 PUFA. The foods tested were chicken meat, fish and linseed oil, shellfish, capsule oil concentrate, egg, cold-smoked mackerel, frozen seafood, squid, hake, salmon and sardine. Sufficient intake for primary prevention in healthy subjects is $250 \mathrm{mg}$ EPA+DHA per day. Consumption of $100 \mathrm{~g}$ of shellfish, frozen seafood, squid, salmon, anchovy fish oil, capsule oil concentrate, cold-smoked mackerel or sardine meets this recommendation. The AHA recommends for general health at least two portions of fish per week, while cardiovascular patients are advised to consume $1 \mathrm{~g}$ of EPA+DHA per day and patients with hypertriglyceraemia to take 2 to $4 \mathrm{~g}$ of EPA+DHA per day. Foods meeting the AHA recommendation for EPA+DHA content were anchovy fish oil, sardine, capsule oil concentrate and cold-smoked mackerel. Eggs and chicken meat contained the least favourable EPA+DHA ratios. The results obtained in this study should be relevant for the establishment of Serbian food composition tables in the field of meat and meat products. 


\title{
Procena sadržaja n-3 polinezasićenih masnih kiselina u različitim namirnicama: procena uticaja na zdravlje
}

\author{
Dejana Trbović, Mirjana Lukić, Radivoj Petronijević, Brankica Lakićević, Mladen Rašeta, \\ Ivana Branković Lazić, Nenad Parunović
}

A p s t r a k $t$ : Cilj ove studije su verifikacija uzoraka hrane označeni kao bogata n-3 polinezasićenim masnim kiselinama (PUFA) i procena njihovog uticaja na zdravlje ljudi u odnosu na evropsko zakonodavstvo. Svi ispitivani uzorci, poput pilećeg mesa, ribljeg i lanenog ulja, školjki, koncentrata ulja u kapsuli, jaja, hladno dimljene skuše, smrznute morske hrane, lignji, oslića i lososa, kao i sardine, ocenjeni su zbog njihovog doprinosa količini n-3 PUFA i odnos n-6 / n-3 PUFA u odnosu na evropske propise. Izvršena je ekstrakcija lipida iz uzoraka i ispitano je kapilarnom gasnom hromatografijom sa detekcijom plamenske jonizacije. Unos 250 mg eikosapentaenske kiseline plus dokozaheksanske kiseline (EPA +DHA) dnevno, koji je dovoljan za primarnu prevenciju kod zdravog subjekta, za $100 \mathrm{~g}$ jestivog dela školjki, smrznutih morskih plodova, lignji i lososa, ribljeg ulja, koncentrata kapsula ulja, hladno dimljena skuša i sardina. Evropska uredba definiše visoki nivo n-3 PUFA kao hranu sa sadržajem od najmanje 0,6 g/ $100 \mathrm{~g}$ a-linolenske kiseline ili najmanje $80 \mathrm{mg} / 100 \mathrm{~g}$ EPA + DHA. To znači da su laneno i riblje ulje najprikladnije za prvu preporuku. Hrana, poput jestivog dijela školjkaša, smrznute morske hrane, lignje, oslić i losos, sardina, hladno dimljeni skuša, koncentrat ulja u kapsuli i riblje ulje ispunjava drugu preporuku. U pogledu ishrane, najmanje povoljni uzorci su jaja i pileće meso. Bliži odnos PUFA n-6/n-3 neophodan je za prevenciju i lečenje hroničnih bolesti. Rezultati dobijeni ovom studijom trebalo bi da budu relevantni za formiranje tabela hranjivih vrednosti proizvoda.

Ključne reči: određivanje ukupne masti, n-3 PUFA, n-6 PUFA, odnos n-6/n-3 PUFA

Disclosure statement: The authors declare they have no conflict of interest.

Acknowledgment: Results presented in this review paper have been financed by the Ministry of Education, Science and Technological Development of Republic of Serbia, in accordance with the Contract on conducting and financing of research of Scientific-Research Organization in 2020, No: 451-03-68/2020-14/200050, from 24.01.2020.

\section{References}

Agrawal, R. \& Gomez-Pinilla, F. (2012). Metabolic syndrome in the brain: deficiency in omega-3 fatty acid exacerbates dysfunctions in insulin receptor signaling and cognition. The Journal of Physiology, 590, 2485-2499. doi: 10.1113/ jphysiol.2012.230078

Arts, M. T., Ackman, R. G. \& Holub, B. J. (2001). "Essential fatty acids" in aquatic ecosystems: a crucial link between diet and human health and evolution. Canadian Journal of Fisheries and Aquatic Sciences, 58, 122-137. doi. org/10.1139/f00-224

Ćirković, M., Trbović, D., Ljubojević, D. \& Đorđević, V. (2011). Meat quality of fish farmed in polyculture in carp ponds in Republic of Serbia. Tehnologija Mesa, 52, 106-121. https://scindeks.ceon.rs/article. aspx?artid=0494-98461101106C

Djordjevic, V., Trbovic, D., Lakicevic, B., Nastasijevic, I., Jankovic, V., Baltic, T. \& Dimitrijevic, M. (2016). Microbiological safety and quality of salmon: health benefits and risk. Meat Technology, 57, 120-125. http://www. journalmeattechnology.com/index.php/meat_technology/ article/view/17
EFSA Panel on Dietetic Products, Nutrition, and Allergies (NDA) (2010). Scientific Opinion on Dietary Reference Values for fats, including saturated fatty acids, polyunsaturated fatty acids, monounsaturated fatty acids, trans fatty acids, and cholesterol. EFSA Journal, 8(3), 1461. 1-107. Available online: www.efsa.europa.eu

Gibson, R. A., Neumann, M. A., Lien, E. L., Boyd, K. A. \& Tu, W. C. (2013). Docosahexaenoic acid synthesis from alpha-linolenic acid is inhibited by diets high in polyunsaturated fatty acids. Prostaglandins Leukotrienes and Essential Fatty Acids, 88, 139-146. doi:10.1016/j.plefa.2012.04.003

Horrobin, D. F. (1995). Abnormal membrane concentrations of 20 and 22-carbon essential fatty acids: a common link between risk factors and coronary and peripheral vascular disease. Prostaglandins Leukotrienes and Essential Fatty Acids, 53, 385-396. https://doi.org/10.1016/09523278(95)90101-9

Hunter, B. J. \& Roberts, D. C. K. (2000). Potential impact of the fat composition of farmed fish on human health. Nutrition Research, 20, 1047-1058. doi: 10.1016/S02715317(00)00181-0 
ISO 5509:2000. Animal and vegetable fats and oils - Preparation of methyl esters of fatty acids. International Organization for Standardization, Geneva, Switzerland.

Lichtenstein, A. H., Appel, L. J., Brands, M., Carnethon, M., Daniels, S., Franch, H. A., Franklin, B., Kris-Etherton, P., Harris, W. S., Howard, B., Karanja, N., Lefevre, M., Rudel, L., Sacks, F., Van Horn, L., Winston, M. \& Wylie-Rosett, J. (2006). Diet and lifestyle recommendations revision: A scientific statement from the American Heart Association Nutrition Committee. Circulation, 114, 82-96. doi: 10.1161/CIRCULATIONAHA.106.176158

Milićević, D., Vranić, D., Mašić, Z., Parunović, N., Trbović, D., Nedeljković-Trailović, J. \& Petrović, Z. (2014). The role of total fats, saturated/unsaturated fatty acids and cholesterol content in chicken meat as cardiovascular risk factors. Lipids in Health and Disease, 13, 42. doi:10.1186/1476-511X-13-42

Pavlovski, Z., Hopic, S., Lukić, M., (2011). Housing systems for layers and egg quality. Biotechnology in Animal Husbandry, 17,197-201. DB - AGRIS SN - 1450-9156T3

Penko, A., Polak, T., Lušnic-Polak, M., Požrl, T., Kakovič, D., Žlender, B. \& Demšar, L. (2015). Oxidative stability of n-3-enriched chicken patties under different package-atmosphere conditions. Food Chemistry, 168, 372-382. doi: 10.1016/j.foodchem.2014.07.075

Lušnic, Polak M, Demšar, L., Luzar, U. \& Polak, T. (2017). Can long chain n-3 fatty acids from feed be converted into very long chain n-3 fatty acids in fillets from farmed rainbow trout (Oncorhynchus mykiss)? 59th International Meat Industry Conference MEATCON2017. 1-4 October 2017, Zlatibor, Serbia. IOP Publishing IOP Conf. Series: Earth and Environmental Science 85 (2017) 012008. doi:10.1088/1755-1315/85/1/012008

Simopoulos, A. P. (2002). The importance of the ratio of omega-6/omega-3 essential fatty acids. Biomedicine and Pharmacotherapy, 56(8), 365-379. doi: 10.1016/s07533322(02)00253-6.

Paper received: February $25^{\text {th }} 2020$.

Paper corrected: June $24^{\text {th }} 2020$.

Paper accepted: June $24^{\text {th }} 2020$.
Simopoulos, A. P. \& Cleland, L. G. (2003). Omega-6/Omega-3 Essential Fatty Acid Ratio: The Scientific Evidence, World Review of Nutrition and Dietetics 92, Karger, Basel, Switzerland.

Simopoulos, A. P. (2004). Omega-6/Omega-3 Essential Fatty Acid Ratio and

Chronic Diseases. Food Reviews International, 20, 77-90. DOI: 10.1081/FRI-120028831

Simopoulos, A. P. (2008). The importance of the omega-6/omega-3 Fatty Acid ratio in cardiovascular disease and other chronic diseases. Experimental Biology and Medicine (Maywood), 233, 674-688. doi: 10.3181/0711-MR-311

Simopoulos, A. P., Bourne, P. G. \& Faergeman, O. (2013). Bellagio Report on Healthy Agriculture, Healthy Nutrition, Healthy People. Nutrients, 5, 411-423. doi: 10.3390/ nu5020411

Spiric, A., Trbovic, D., Vranic, D., Djinovic, J., Petronijevic, R. \& Matekalo-Sverak, V. (2010). Statistical evaluation of fatty acid profile and cholesterol content in fish (common carp) lipids obtained by different sample preparation procedures. Analitica Chimica Acta, 672, 66-71. doi: 10.1016/j.aca.2010.04.052

Trbović, D., Vranić, D., Djinović-Stojanović, J., Matekalo-Sverak, V., Djordjević, V., Babić, J., Spirić, D., Petronijević, R., Spirić, A. (2012). Fatty acid profile in rainbow trout (Oncorhynchus mykiss) as influenced by diet. Biotechnology in Animal Husbandry, 28, 563-573. https://doi.org/10.2298/BAH1203563T

von Schacky C., Fisher, S. \& Weber, P. C. (1985). Long-term effects of dietary marine $\omega 3$ fatty acids upon plasma and cellular lipids, platelet function and eicosanoid formation in humans. Journal of Clinical Investigation, 76, 1626-1631. doi:10.1172/JCI112147

Živković, D., Lilić, S., Stajić, S., Vranić, D., Trbović, D. \& Stanišić, N. (2017). Effect of extruded flaxseed enriched diet on physico-chemical and sensory characteristics of broiler meat. Biotechnology in Animal Husbandry, 33, 221-231. doi: https://doi.org/10.2298/BAH1702221Z 